\title{
Essential Oil Variation and Trace Metals Content in Garden Sage (Salvia officinalis L.) Grown at Different Environmental Conditions
}

\author{
Mohammed Sanad Abu Darwish ${ }^{1}$ \\ ${ }^{1}$ Deapartement of Essential \& Apllied Sciences, Shouback University College, Al-Balqa Applied University, \\ Shoubak, Jordan \\ Correspondence: Mohammed Sanad Abu Darwish, Deapartement of Essential \&Apllied Sciences, Shouback \\ University College, Al-Balqa Applied University, Shoubak, Jordan. Tel: 962-795-171-140. E-mail: \\ maa973@yahoo.com
}

Received: June 25, 2013 Accepted: July 26, 2013 Online Published: February 15, 2014

doi:10.5539/jas.v6n3p209 URL: http://dx.doi.org/10.5539/jas.v6n3p209

\begin{abstract}
This study was conducted to determine the essential oil variation and concentrations of certain trace metals (Co, $\mathrm{Cu}, \mathrm{Fe}, \mathrm{Mn}$ and $\mathrm{Zn}, \mathrm{Pb}, \mathrm{Cd}$ ) in the sage plant (Salvia officinalis L.) grown in their different geographic natural environment. The samples of Salvia officinalis were collected from Jeresh and Ajloune, Ma' an and Tafilah, and Amman located in their natural original regions in the north, south, and middle locations of Jordan, respectively. The results showed a wide variation of essential oil contents among $S$. officinalisgrown in different variable natural environment. The range varied from $0.87 \%$ in Amman to $2.8 \%$ in Jarash. In general, the oil content in S. officinalis grown in the north regions was higher than recorded in the middle and south regions. The essential oil content in $S$. officinalis grown in Jarash and Ma'an were higher than recoded in other investigated groth regions. Trace metal concentrations in all investigated samples were varied.The most toxic trace metals $\mathrm{Co}, \mathrm{Pb}$, and $\mathrm{Cd}$ were not detectable in all studied samples. Fe metal recorded the highest concentration which varied from $834.5 \mathrm{mg} / \mathrm{kg}$ in Ajloun to $1743 \mathrm{mg} / \mathrm{kg}$ in Ma'an. $\mathrm{Cu}$ recoded the lowest mean levels among all detected metals and varied from $6.60 \mathrm{mg} / \mathrm{kg}$ in Amman to $9.25 \mathrm{mg} / \mathrm{kg}$ in Ajloune .The highest mean levels of Mn were recorded in the southern regions in Tafilah and Ma'an (53.7 and $50.4 \mathrm{mg} / \mathrm{kg}$, respectively), while the lowest was recorded in the middle region in Amman (26.10 mg/kg). Zn concentration varied from $27.80 \mathrm{mg} / \mathrm{kg}$ in Ma'an to $42.72 \mathrm{mg} / \mathrm{kg}$ in Tafillah. All of detected metals were within the range of permissible limit for medicinal plants and lower than that detected in $S$. officinalis originated from other local and global habitats. The essential oil and trace metals contents in $S$. officinalis were mainly affected by variable natural climatic conditions. Moreover, the current study showed that $S$. officinalis grown in some locations of Jordan are characterized by low trace metals contents and can safely be used for pharmaceutical and edible purposes without any hazardous effect on human health.
\end{abstract}

Keywords: essential oil, jordan, sage, trace metals

\section{Introduction}

Garden sage (Salvia officinalis L.) is a perennial medicinal plant with woody stems, and grayish leaves belonging to the family Lamiaceae that comprises over 900 species all over the world. It's native to the Mediterranean region in which twenty species of Salvia were found grow wildly in Jordan (Al-Eisawi, 1996). S. officinalis is a popular plant in Jordanian folk medicine and used for edible consumption and herbal remedy as a source of therapeutically active essential oil (Amr \& Đorđević, 2000). Sage extracts, mostly essential oil, are also widely used in the drug, beverage, cosmetic and fragrance industries. Various studies have proved that the essential oil extracts of garden sage exhibited antimicrobial activities against some pathogenic microorganisms and food borne bacteria (Hayouni et al., 2008; Klaus et al., 2008). Moreover, the individual secondary metabolites of sage could exhibit various pharmacological activities such as anesthetic, antihistaminic, antirheumatic, diuretic, expectorant, insecticidal, purgative (monoterpenes); analgesic, antiarhythmic, antiepileptic, spasmolitic, anthelmintic, antiinflammatory, antitumorous, hypotensive, and sedative (Velickovic et al., 2003).

Trace metals of $S$. officinalis have an important biological role in human, animal and plant health. Trace metals content in medicinal plant research conducting is of great interest because of their effect on the biological active compounds in medicinal plants and may cause serious effects on human health. Thus, the maximum permissible limits of toxic metals in medicinal plants such as cadmium and lead were reported by World Health Organization, 
(2007). In Jordan, a recent study was conducted to determine $\mathrm{Pb}$ concentration in seventy nine popular samples of medicinal plants (Alomary et al., 2013), they found that $\mathrm{Pb}$ concentration in the most samples was higher than recommended values by World Health Organization. The mean $\mathrm{Pb}$ levels were ranged between 13.1 and $16.9 \mu \mathrm{g} / \mathrm{g}$ in the most and less commonly used herbs (Alomary et al., 2013). In addition, many worldwide research studies have been conducted to evaluate the content of heavy metals in certain medicinal plants consumed by popular or used in pharmaceutical industries (Amr \& Đorđević, 2000; Malencic et al., 2003; Chan, 2003; Angelova et al., 2005; Szentmihályi \& Then, 2007; Blagojević et al., 2009; Abu-Darwish et al., 2010).

The content of essential oil and heavy metals in medicinal plants can be affected by environmental conditions (Maksimovic et al., 2007) and geochemical characteristics of soil or location in which the plant is grow (Chan, 2003; Blagojević et al., 2009; Abu-Darwish et al., 2010). Therefore, the present study was conducted to find out the effect of environmental conditions on the yield of essential oil and certain trace metal contents in S. officinalis grown naturally in different geographical locations of Jordan.

\section{Materials and Methods}

\subsection{Plant Material}

Aerial parts of $S$. officinalis were collectedin vegetative period during April, in five localities of Jordan: Ma'an (South Jordan); Tafillah (South Jordan); Jerash (North Jordan); S5- Ajloun (North Jordan); and Amman (Middle Jordan). Voucher specimens were deposited at the Herbarium of Shoubak University College- Al-Balqa Applied University. The plant material was dried in draughty place at about $20^{\circ} \mathrm{C}$, all specimens were identified on the basis of macroscopic characteristics by comparison with authentic sample and a voucher specimen was deposited at the Herbarium of Al-Shoubak University College. The dried samples of S. officinalis were separately crushed and mild into small pieces and sieved through $(0.5 \mathrm{~mm})$ mesh sieve.

\subsection{Determination of Essential Oil}

Essential oil contents were extracted from dried aerial parts of the all collected samples of Sage plant by the hydro-distillation method using a Clevenger-type apparatus (British Pharmacopeia, 1998) similar to (European Pharmacopoeia, 2007), using $50 \mathrm{~g}$ of the dried mild and sieved plant and $500 \mathrm{~mL}$ of water in $1000 \mathrm{~mL}$ round bottomed flask. Distillation time was $2 \mathrm{~h}$ at a rate of 2-3 $\mathrm{min}^{-1}$ the values reported are the mean of at least three distillations and three replications for each specimen.

\subsection{Determination of Heavy Metals Content in Sage Plant Samples}

The content of $\mathrm{Co}, \mathrm{Cu}, \mathrm{Fe}, \mathrm{Mn}$ and $\mathrm{Zn}, \mathrm{Pb}$, and $\mathrm{Cd}$ in particular sage samples were analyzed using Atomic AbsorptionFlame Emission Spectrophotometer Varian Spectro AA.200as described by (Al-Alawi \& Mandiwana, 2007). Cathode lamps used as radiation source. Air acetylene gas was used for all the experiments. The Absorption wavelength for the determination of each metal together with its liner working range and correlation coefficient of calibration graphs are given in Table 1 . The plant samples were oven dried at $70^{\circ} \mathrm{C}$ for $24 \mathrm{~h}$ until the dry weight was constant. The dried samples were then ground and passed through a $0.2 \mathrm{~mm}$ plastic sieve. Then, $0.5 \mathrm{~g}$ of plant sample was wet digested with an Ultra-pure nitric acid $\left(\mathrm{HNO}_{3}(10-15 \mathrm{~mL})\right.$ in a polyethylene test tube using a heating block digestion unit at $120^{\circ} \mathrm{C}$. The final solution was filtered into a 25 or $50 \mathrm{~mL}$ volumetric flask through a $45-\mu \mathrm{m}$ filter paper and diluted to the mark with ultra-pure water. Ultra-pure water was used for all dilutions and sample preparation. Analytical results have evaluated by statistical analysis system. The standard error values of the means were calculated to compare the site categories.

Table 1. Operating parameters for working elements

\begin{tabular}{lllll}
\hline Elements & Wave length(nm) & Lamp intensity $(\mathrm{mA})$ & Slit width(nm) & Correlation coefficient(r) \\
\hline $\mathrm{Pd}$ & 217.0 & $5 \mathrm{~mA}$ & 0.2 & 0.998 \\
$\mathrm{Cd}$ & 228.8 & $4 \mathrm{~mA}$ & 0.5 & 0.998 \\
$\mathrm{Zn}$ & 213.9 & $5 \mathrm{~mA}$ & 1.0 & 0.998 \\
$\mathrm{Cu}$ & 234.7 & $4 \mathrm{~mA}$ & 0.5 & 0.998 \\
$\mathrm{Fe}$ & 248.3 & $5 \mathrm{~mA}$ & 0.2 & 0.998 \\
$\mathrm{Mn}$ & 279.5 & $5 \mathrm{~mA}$ & 0.2 & 0.998 \\
\hline
\end{tabular}




\section{Results and Discussion}

Means of essential oil contents in S. officinalis L. are listed in Table 2. The results revealed a wide variation in the values of essential oil yielded from sage plant grown in different environmental locations. The variation range of oil content varied from 0.87 to $2.80 \%$, reaching minimum and maximum values in Amman and Jeresh located in the middle and northern regions of Jordan, respectively. The results showed that the oil content in all specimens of $S$. officinalis, except that cultivated in Amman (Middle of Jordan) were found to satisfy the requirements of Pharmacopeias such as European Pharmacopoeia, which requires a yield of oil should be $\geq 1.2 \% \mathrm{v} / \mathrm{w}$. calculated with reference to the anhydrous (dried) drug (European Pharmacopoeia, 2007). In south regions, Essential oil was ranged from 1.8 to $2.2 \%$ in specimens collected from Tafillah and Ma'an respectively, while it was increased from 1.20 to $2.8 \%$ in the northern growth areas of Ajloun and Jeresh, respectively. These results were in agreement with the results obtained by Amr and Đorđević (2000), who found that S. officinalis collected during the vegetative period from some middle locations of Jordan, yielded 1.18-1.32\%.

Table 2. Averages of ambient temperatures $\left({ }^{\circ} \mathrm{C}\right)$, rainfall $(\mathrm{mm})$, and relative humidity $(\%)$, and means of essential oils yield (\%), and moisture content (\%) of garden sage cultivated in different environmental regions in Jordan

\begin{tabular}{lllllll}
\hline $\begin{array}{l}\text { Place of Sage } \\
\text { growth }\end{array}$ & $\begin{array}{l}\text { Altitude } \\
(\mathrm{m})\end{array}$ & $\begin{array}{l}\text { Ambient temp. min. } \\
-\max .\left({ }^{\circ} \mathrm{C}\right)\end{array}$ & $\begin{array}{l}\text { Seasonal means of } \\
\text { rainfall }(\mathrm{mm})\end{array}$ & $\begin{array}{l}\text { Relative } \\
\text { humidity }(\%)\end{array}$ & $\begin{array}{l}\text { Moisture } \\
(\%)\end{array}$ & Oil (\%) \\
\hline Ajlune & $800-1150$ & $10.1-18.6$ & 582.2 & 80.20 & $4.9 \%$ & $1.20 \pm 0.17$ \\
Jarash & $520-750$ & $8.5-18.40$ & 445.6 & 68.30 & $3.4 \%$ & $2.80 \pm 0.06$ \\
Amman & $700-1050$ & $6.8-23.5$ & 490.0 & 51.70 & $3.7 \%$ & $0.87 \pm 0.12$ \\
Ma'an & $1069-1100$ & $20.0-32.0$ & 44.20 & 57.80 & $6.1 \%$ & $2.20 \pm 0.17$ \\
Tafelah & $900-1140$ & $11.8-23.4$ & 237.6 & 23.30 & $5.2 \%$ & $1.80 \pm 0.17$ \\
\hline
\end{tabular}

Table 3. Concentration of heavy metals $(\mathrm{mg} / \mathrm{kg})$ in Sage (Saliva Officinalis) in various locations in Jordan

\begin{tabular}{lccccccc}
\hline \multirow{2}{*}{ Location } & \multicolumn{7}{c}{$\mathrm{mg} / \mathrm{kg}$} \\
\cline { 2 - 8 } & $\mathrm{Co} *$ & $\mathrm{Cu}^{*}$ & $\mathrm{Fe}^{*}$ & $\mathrm{Mn}$ & $\mathrm{Zn}$ & $\mathrm{Pb}^{*}$ & $\mathrm{Cd}^{*}$ \\
\hline Ajlune & $<\mathrm{IDL}$ & $9.25 \pm 0.006$ & $834.5 \pm 0.003$ & $39.2 \pm 0.008$ & $41.23 \pm 0.007$ & $<\mathrm{IDL}$ & $<\mathrm{IDL}$ \\
Jarash & $<\mathrm{IDL}$ & $8.27 \pm 0.003$ & $899 \pm 0.007$ & $39.1 \pm 0.006$ & $40.54 \pm 0.0001$ & $<\mathrm{IDL}$ & $<\mathrm{IDL}$ \\
Amman & $<\mathrm{IDL}$ & $6.60 \pm 0.001$ & $1010.5 \pm 0.00$ & $26.1 \pm 0.001$ & $29.71 \pm 0.0001$ & $<\mathrm{IDL}$ & $<\mathrm{IDL}$ \\
Ma`an & $<\mathrm{IDL}$ & $7.20 \pm 0.005$ & $1743 \pm 0.006$ & $53.7 \pm 0.004$ & $27.80 \pm 0.003$ & $<\mathrm{IDL}$ & $<\mathrm{IDL}$ \\
Tafelah & $<\mathrm{IDL}$ & $7.77 \pm 0.006$ & $714.25 \pm 0.002$ & $50.4 \pm 0.003$ & $42.76 \pm 0.001$ & $<\mathrm{IDL}$ & $<\mathrm{IDL}$ \\
\multicolumn{1}{c}{ IDL } & $0.005<$ & $0.003<$ & $0.006<$ & $0.002<$ & $0.001<$ & $0.001<$ & $0.002<$ \\
\hline
\end{tabular}

* are included in accreditation.

Maric et al. (2006) observed that the oil content in S. officinalis was increased in higher altitude than lower. In contrast, the present study showed that the oil content in lower altitude regions of Jarash (520-750 m ab.s.l) and Ma'an (1100-1140 m ab.s.l) was higher than those observed in higher altitudes regions of Tafilah, Ajloun and Amman (2.2-2.8\%) (0.87-1.8), respectively. The same results were reported by Haider et al. (2009) and Takaloo et al. (2012) who found that the lowest oil yields were recorded in plants collected from the relatively higher altitude. However, other factors may be induced the essential oil yields in Jarash and Ma' an such as temperature, soil fertility, locality, and the high sunlight radiation level. It was reported that, the aromatic medicinal plants submitted to high level of sunlight radiation yielded higher content of essential oil than others (Letchamo \& Gosselin, 1995; Silva et al., 2006). Qasaimeh (2012) showed that the average daily solar radiation for the years (2004-2010) in regions closed toMa' an was $6215 \mathrm{Wh} / \mathrm{m}^{2} \cdot \mathrm{d}$ and higher than in Tafilah $5763 \mathrm{Wh} / \mathrm{m}^{2} \cdot \mathrm{d}$ and Amman $5711 \mathrm{Wh} / \mathrm{m}^{2} \cdot \mathrm{d}$. This is indicated by the effect of high sunlight radiation level in Ma' an on the higher yields of oil from S. officinalis. Li et al. (2006) who found that the highest oil yield was in sage plants grown at $45 \%$ of full sunlight. However, this variation indicates the effect of geographical growth location on the yields of essential oils. Such variations could be explained by the effect of environmental factors related to the predominant climatic and geographical differences on various growth areas (Table 3) (Perry et al., 1999; Chan, 2003; Maksimovic et al., 
2007; Abu- Darwish et al., 2010). This is confirmed by the results of oil content recorded in the worldwide regions of Egypt (1.52-1.65\%) (Khalil et al., 2008), Lithuania (0.7-1.4\%) (Bernotienė et al., 2007), Bosnia and Herzegovina (0.29\%-1.07\%) (Maric et al., 2006), Algeria 0.9\% (Dob et al., 2007) and Spain 1.4-2.0 (Arraiza et al., 2012).

The concentration of $\mathrm{Cu}$ metal ranged from 6.6 in Amman to $9.25 \mathrm{mg} / \mathrm{kg}$ in Ajloune. These concentrations were within the average content of $\mathrm{Cu}$ in dry plant material which is reported to be $2.0-20 \mathrm{mg} / \mathrm{kg}$ by Malencic et al. (2003) indicating that all the investigated growth regions are not contaminated with $\mathrm{Cu}$ metal. These results were in agreement with the results of our previous study conducted in the south Shouback region and showed that $\mathrm{Cu}$ concentrations in $S$. officinalis cultivated at 15 and $30 \mathrm{~cm}$ inter-raw spaces were 7.32 and $7.02 \mathrm{mg} / \mathrm{kg}$, respectively. In contrast, Amr and Đorđević (2000) found that $\mathrm{Cu}$ metal concentration in S.officinalis grown in Al Dbajbe near Amman-Sahab highway was ranged from 61 to $70 \mathrm{mg} / \mathrm{kg}$ and higher than the permissible limits.

$\mathrm{Fe}$ is one of the most essential elements for living organism's cells. The results showed a wide variation of Fe concentration in S. officinalis. It was ranged from 834.5 to $1743 \mathrm{mg} / \mathrm{kg}$ in the northern (Ajloun) and southern (Ma'an) regions of Jordan. However, they were within the concentration limits in dry plant material $(1000 \mathrm{mg} / \mathrm{kg})$ (Malencic et al., 2003). These differences in Fe concentrations could be explained by the assumption of Shad et al. (2008) who suggested that high concentration of Fe in plants may be due to the foliar absorption from the surroundings air. This is supported by the results of Fe concentrations in S.officinalis cultivated in worldwide regions which revealed a wide variation in the values of Fe concentrations. They were 297.4, 453.77 and 450 $\mathrm{mg} / \mathrm{kg}$ in Turkey (Başgel \& Erdemoğlu, 2006), Serbia (Malencic et al., 2003) and Romania (Ştef et al., 2010), respectively. On the other hand, Yeritsy and Economakis (2002) reported that Fe concentration in leaves could be increased by higher concentration of $\mathrm{Fe}$ in the growth nutrient medium indicating that the soils of Ma'an and Amman regions are rich source content of $\mathrm{Fe}$.

Mn concentration in all collected samples of $S$. officinalis from different investigated regions were ranged from $26.1 \mathrm{mg} / \mathrm{kg}$ in Amman, the middle region to $53.7 \mathrm{mg} / \mathrm{kg}$ in Ma'an and Tafilah, the southern regions of Jordan. The contents of $\mathrm{Mn}$ in S. officinalis originated in the north regions were 39.2 and $39.1 \mathrm{mg} / \mathrm{kg}$ in Ajloun and Jarash, respectively. They were higher than found in the middle and lower than recorded in the south regions of Jordan. However, the concentrations of $\mathrm{Mn}$ in S. officinalis originated in the different geographical locations of Jordan were higher than the critical threshold for Mn deficiency in plant $(<10 \mathrm{ppm})$, These results were in agreement with previous results obtained from $S$. officinalisgrowen at $30 \mathrm{~cm}$ inter-raw spacing and harvested during the vegetative period in the south shouback region (Abu-darwish et al., 2010).

The results of $\mathrm{Zn}$ metal concentration in S. officinalis showed a limited variation among the different geographic origin regions. The range varied from 27.80 in Ma' an to $42.76 \mathrm{mg} / \mathrm{kg}$ in Tafilah, the southern regions of Jordan. In the north, it was $41.2 \mathrm{mg} / \mathrm{kg}$ in Jarash and $40.54 \mathrm{mg} / \mathrm{kg}$ in Ajloun while it was $29.71 \mathrm{mg} / \mathrm{kg}$ in the middle region. The same findings were observed by Amr and Đorđević (2000) who found that the concentration of $\mathrm{Zn}$ in S.officinalis originated from middle of Jordan varied from 22 to $29 \mathrm{mg} / \mathrm{kg}$. On the other hand, Malencic et al. (2003) reported that the concentration of $\mathrm{Zn}$ in plant may vary between $30-150 \mathrm{mg} / \mathrm{kg}$, but usually it is between $20-50 \mathrm{mg} / \mathrm{kg}$. In general, the low contents of $\mathrm{Zn}$ in all studied samples indicated to non polluted soil environment and/or in locations faraway from industrial and heavy traffic activities which were reported the main factors of plant growth soil pollution with heavy metals (Angelova et al., 2005; Blagojević et al., 2009; Stancheva et al., 2009). In conclusion, the results of the present study revealed that $S$. officinalis growen in Jordan is a safe medicinal plant containing sufficient amount of a biological active essential oil that is clearly influenced by metrological and environmental factors. S. officinalis originated within investigated southern, middle and northern regions of Jordan are free from hazardous heavy metals such as $\mathrm{Cd}, \mathrm{Pb}$. Moreover, the surrounding environments of $S$. officinalis original locations are not polluted with heavy metals. Further studies on the composition of $S$. officinalis essential oil, grown in different Jordan environments are recommended.

\section{References}

Abu-Darwish, M. S., Abu-Dieyeh, Z. H., Al-Fraihat, A. H., Al-dalain, S. Y., Afifi, F. U., \& Al-Tabbal, J. A. (2010). Determination of essential oils and heavy metals accumulation in Salvia officinaliscultivated in three intra-raw spacing in ash-shoubak, Jordan. International Journal of Agriculture\& Biology, 13, 981985.

Al-Alawi, M. M., \& Mandiwana, K. L. (2007). The use of Aleppo pine needles as a bio-monitor of heavy metals in the atmosphere. Journal of Hazardous Materials, 148, 43-46. http://dx.doi.org/10.1016/j.jhazmat.2007.02.001

AL-Eisawi, D. M. (1996). Vegetation of Jordan. Book published by UNESCO (ROSTAS). Cairo Office: Cairo. 
Al-Omary, A., El-Jamal, E., Al-momani, I., Attiyat, A., \& Obeidat, S. (2013). Pb in medicinal plants from Jordan. Enviro Chem Lett, 11, 55-63. http://dx.doi.org/10.1007/s10311-012-0378-y

Amr, S., \& Đorđević, S. (2000). The investigation of the quality of Sage (Salvia officinalis) originating from Jordan. FACTA Universitatis Series: Working Living Environmental Protection, 5, 103-108.

Angelova, V., Ivanov, K., \& Ivanov, R. (2005). Heavy metal content in plants from family Lamiaceae cultivated in an industrially polluted region. Journal of Herbs, Spices \& Medicinal Plants, 11, 37-46. http://dx.doi.org/10.1300/J044v11n04_05

Arraiza, M. P., Arrabal, C., \& López, J. V. (2012). Seasonal Variation of Essential Oil Yield and Composition of Sage (Salvia officinalisL.) Grown in Castilla - La Mancha (Central Spain), Notulae Botanicae Horti Agrobotanici Cluj-Napoca, 40(2), 106-108.

Başgel, S., \& Erdemoğlu, S. B. (2005). Determination of mineral and trace elements in some medicinal herbs and their infusions consumed in Turkey. Science of the Total Environment, 359, 82-89. http://dx.doi.org/10.1016/j.scitotenv.2005.04.016

Bernotienè, G., Nivinskienė, O., Butkienè, R., \& Mockute, D. (2007). Essential oil composition variability in sage (Salvia officinalis L.). CHEMIJA, 18(4), 38-43.

Blagojević, N., Damjanović-Vratnica, B., Vukašinović-Pešić, V., \& Đurović, D. (2009). Heavy Metals Content in Leaves and Extracts of Wild-Growing Salvia Officinalisfrom Montenegro. The Polish Journal of Environmental Studies, 18(2), 167-173.

British Pharmacopeia. (1998). Her Majesty's Stationery office, London, 2, 137-138.

Chan, K. (2003). Some aspects of toxic contaminants in herbal medicines. Chemosphere, 52, 1361-1371. http://dx.doi.org/10.1016/S0045-6535(03)00471-5.

European Pharmacopoeia. (2007). Strasbourg, France: Council of Europe 2 (6th ed). Kelp, monograph 1426.

Haider, F., Narendra, K., Banerjee, S., Naqvi, A. A., \& Bagchi, G. D. (2009). Effect of altitude on the essential oil constituents of Artemisia roxburghiana Besser var. purpurascens (Jacq.) Hook. Journal of Essential Oil Research, 21(4), 303-304. http://dx.doi.org/10.1080/10412905.2009.9700177

Hayouni, E. A., Chraief, I., Abedrabba, M., Bouix, M., Leveau, J. Y., Mohammed, H., \& Hamdi M. (2008). Tunisian Salvia officinalis L. and Schinusmolle L. essential oils: Their chemical compositions and their preservative effects against Salmonella inoculated in minced beef meat. International Journal of Food Microbiology, 125(3), 242-251. http://dx.doi.org/10.1016/j.ijfoodmicro.2008.04.005.

Khalil, M. Y., Kandil, M. A., \& Swaefy, H. M. F. (2008). Effect of three Different Compost Levels on Fennel and Salvia Growth Character and their Essential Oils. Res. J. Agric. Biol. Sci., 4, 34-39.

Khan, M. A., Ahmad, I., \& Ur Rahman, I. (2007). Effect of Environmental Pollution on Heavy Metals Content of Withaniasomnifera. Journal of the Chinese Chemical Society, 54, 339-343.

Klaus, A., Beatovia, S. D. V., Niksia, M. P., Jelaaia, S. A., Nedovia, V. K., \& Petrovia, T. S. (2008). Influence of Ethereal Oils Extracted from Lamiaceae Family Plants on Some Pathogen Microorganisms, Proc. Nat. Sci, Matica Srpska Novi Sad, 115, 65-74.

Letchamo, W., \& Gosselin, A. (1995). Effects of supplemental lighting and soil water levels on growth, essential oil contend and composition of two thyme (Thymus vulgaris L) clonal selections. Canadian Journal of Plant Science, 75(1), 231-238. http://dx.doi.org/10.4141/cjps95-044

Li, Y. L., Craker, L. E., \& Potter, T. (1995, August). Effect of light level on essential oil production of sage (Salvia officinalis) and thyme (Thymus vulgaris). In International Symposium on Medicinal and Aromatic Plants 426 (pp. 419-426). Retrieved from http://ww.actahort.org/books/426/426_46.htm

Maksimovic, M., Vidic, D., Milos, M., olic, M. E. S, Zic, S. A., \& Siljak-Yakovlev, S. (2007). Effect of the environmental conditions on essential oil profile in two Dinaric Salvia species: S. brachyodonVandas and S. officinalis L. Biochemical Systematic and Ecology, 35, 473-478. http://dx.doi.org/10.1016/j.bse.2007.02.005.

Malencic, D. R., Kevesan, Z. S., \& Popovic, M. T. (2003). Mineral composition of selected Salvia species growing wild in the Vojvodina province. Proc. nat. sci. Matica Srpska Novi sad, 105, 25-33. http://dx.doi.org/10.2298/ZMSPN0305025M 
Maric, S., Maksimovic, M., \& Milos, M. (2006). The impact of the locality altitudes and stages of development on the volatile constituents of Salvia officinalis L. from Bosnia and Herzegovina. Journal of Essential Oil Research, 18(2), 178-180. http://dx.doi.org/10.1080/10412905.2006.9699060

Misra, A., \& Sharma, S. (1991). Critical Zn concentration for essential oil yield and menthol concentration of Japanese mint. Nutrient Cycling in Agroecosystems, 29(3), 261-265. http://dx.doi.org/10.1007/BF01052394

Perry, N. B., Anderson, R. E., Brennan, N. J., Douglas, M. H., Heaney, A. J., McGimsey, J. A., \& Smallfield, B. M. (1999). Essential oils from Dalmation sage (Salvia officinalis L.): variations among individuals, plant parts, seasons and sites. Journal of Agriculturaland Food Chemistry, 47, 2048-2054. http://dx.doi.org/10.1021/jf981170m

Qasaimeh, A. (2012). Solar Energy Optimization through Seasons: Case Study in Jordan. Smart Grid and Renewable Energy, 3, 275-281. http://dx.doi.org/10.4236/sgre.2012.34038.

Shad, A. K., Lajbar, K., Iqbal, H., Khan, B. M., \& Naveed A. (2008). Profile of Heavy Metals in selected Medicinal plants. Pakistan journal of Weed Science Research, 14, 101-110.

Silva, F., Pinto, J. E. B. P., Cardoso, M. das G., Nascimento, E. A., Nelson, D. L., Sales, J. de F., \& Mol, D. J. de S. (2006). Influence of Radiation Level on Plant Growth, Yield and Quality of Essential Oil in Carqueja. Ciênciae Agrotecnologia Lavras, 30(1), 52-57. http://dx.doi.org/10.1590/S1413-70542006000100007.

Stancheva, I., Geneva, M., Hristozkova, M., Boychinova, M., \& Markovska, Y. (2009). Essential Oil Variation of Salvia officinalis (L.), Grown on Heavy Metals Polluted Soil. Biotechnology \& Biotechnological Equipment, 23, 373-376.

Ştef, D. S., Gergen, I., Traşcă, T. I., Hărmănescu, M., Ştef, L., Drugă, M., ... Hegheduş-Mîndru, G. (2010). Screening of 33 Medicinal Plants for the Microelements Content.Animal Science and Biotechnologies, 43(1), 127-132.

Szentmihályi, K., \& Then, M. (2007). Examination of microelements in medicinal plants of the Carpathian basin. Acta Alimentaria, 36(2), 231-236. http://dx.doi.org/10.1556/AAlim.36.2007.2.9

Takaloo, S. G., Hassani, A., Hassanpouraghdam, M. B., Meshkatalsadat, M. H., Pirzad, A., \& Heidari, M. (2012). Essential Oil Content and Composition of Thymus migricus Klokov \& Desj-Shost. Affected by Plant Growth Stage and Wild Habitat Altitude. Romanian Biotechnological Letters, 17(1), 6983-6988.

Velickovic, A. S, Ristic, M. S., Velickovic, D. T., Ilic, S. N., \& Mitic, N. D. (2003). The Possibilities of the Application of Some Species of Sage (Salvia L.) as Auxiliaries in the Treatment of Some Diseases. Journal of the Serbian Chemical Society, 68(6), 435-445. http://dx.doi.org/10.2298/JSC0306435V

World Health Organization. (2007). Dept. of Technical Cooperation for Essential Drugs and Traditional Medicine.WHO guidelines for assessing quality of herbal medicines with reference to contaminants and residues. World Health Organization. Geneva, Switzerland.

Yeritsyan, N., \& Economakis, C. (2002). Effect of Nutrient Solution's Iron Concentration on Growth and Essential Oil Content of Oregano Plants Grown in Solution Culture. ActaHorticulturae (ISHS), 576, 277 283. Retrieved from http://www.actahort.org/books/576/576_41.htm

\section{Copyrights}

Copyright for this article is retained by the author(s), with first publication rights granted to the journal.

This is an open-access article distributed under the terms and conditions of the Creative Commons Attribution license (http://creativecommons.org/licenses/by/3.0/). 